\title{
RA における下肢多関節人工関節置換例の検討
}

\begin{tabular}{|c|c|c|c|c|c|}
\hline 柳 & 田 & 晴 & 久. 近 & 藤 & 正 \\
\hline 真 & 島 & 龍 & 興·篠 & 原 & 典 \\
\hline 横 & 山 & 庫 & 一郎·原 & 田 & \\
\hline 豊 & 田 & 雅 & 樹·林 & & 廣 \\
\hline
\end{tabular}

\section{Multiple Joint Replacement for Rheumatoid Arthritis Patients} by

\author{
Haruhisa Yanagida, Masakazu Kondo, Tatsuoki Mashima, \\ Norio Shinohara, Koichiro Yokoyama, Hiroshi Harada, \\ Masaki Toyoda and Kousei Lin \\ Department of Orthopaedic Surgery, \\ National Fukuoka Central Hospital, Fukuoka, Japan
}

\begin{abstract}
The results of multiple joint replacement for 62 rheumatoid arthritis patients are reported. Subjects were followed up for an average of 37 months. In 52 patients, walking ability improved or was maintained but in 5 patients it worsened and 5 patients had died. Factors which worsened the patient's walking ability were rheumatic disorders of the foot, ankle, and cervical spine and compression fractures of the thoracolumbar spine due to osteoporosis. Extra care must be given for these factors after multiple joint replacement in rheumatoid arthritis patients.
\end{abstract}

Kew words : Multiple Joint Replacement (多関節置換術), Rheumatoid Arthritis (慢性関 節リウマチ)

\section{は じめに}

慢性関節りウマチ（以下 RA）による関節破壊が下 肢の多関節に及ぶ症例では, 歩行能力の獲得のために 多関節の人工関節置換術をやむなくされることがある. 今回多関節置換例の術後成績を調査し検討した.

\section{対 象}

対象は 1972 年から 1993 年 12 月までに手術をうけ 当科で follow している 3 関節以上置換した 62 例で, 男性 4 例, 女性 58 例. 発症年齢は 5 才から 69 才, 平 均 41.9 才. 初回人工関節手術時年齢は 29 才から 69 才, 平均 54.2 才. 発症から初回手術までの期間は 1 年から 38 年, 平均 13 年 3 力月. 最終手術後 follow
期間は 4 カ月から 8 カ月, 平均 3 年 1 カ月であった. 3 関節置換例が 27 例, 4 関節置換例が 35 例であった. なお今回の対象は全関節を当科で手術したものではな く, 他施設で人工関節置換術をうけさらに当科で置換 術をうけた症例も含まれる.

今回の調査に当たって, 症例を $2 つ の$ Group に分 けた.すなわち関節破壊の度に順次置換術を行った例 は50例あり，これをGroup 1 とした. Group 2 は 術前すでに寝たきりかそれに近い状態で，1回の入院 で計画的な多関節置換を行った例で, これが 12 例で あった. 以上の症例につき, 術前後での移動動作の推 移, RA 活動性の推移, レ線評価などを行い, RAに おける下肢多関節置換例での問題点を考察した. 


\section{結果}

62 例のうち調查時死亡例は 5 例あり（表 1 ), 死亡 年齢は 48 才から 71 才, 平均 61.2 才, 最終手術から 死亡までの期間は 2 年から 4 年 6 力月, 平均 3 年 3 力 月，死因は肺炎 2 例，脳出血 1 例，心不全 1 例，急性 㬸炎 1 例で直接人工関節置換に関連するものはなかっ た. 3 関節置換例が 3 例, 4 関節置換例が 2 例であっ た。

Group 1 とGroup 2 で患者の背景に何らかの差が あるかを調査したが (表 2 )，Group 2 がやや発症年 齢が若いこと以外には Group 間には差はなかった。

移動動作の評価法として藤林の Class 分類を用い た ${ }^{1)}$.これはClass 3，4をそれぞれ a， b， c，dに 分類したもので, $3 \mathrm{c}$ が庭程度までの歩行， $3 \mathrm{~d}$ が室内 のみの歩行など実用的に分類されている（表 3).

移動動作の推移を Group 別に示す（図 1). Group 1 では全例で退院時には Class 3へと改善していた。 退院時から調査時までにほとんどの症例では移動動作 が維持あるいは改善していたが，3例では悪化してい た. Group 2 では術前に全例がClass 4 であったが こちらも退院時には全例が $3 \mathrm{~d}$ 以上すなわち室内歩行 は可能となっていた. しかし Group 2 でも 2 例にお いては調査時に悪化していた。

移動動作が悪化した 5 例についてみてみると（表4), Group 1 が 3 例, Group 2 が 2 例で, 最終手術から 調査時までの期間は 1 年 10 力月から 6 年 9 力月，平 均 4 年 5 カ月であった．原因は，足部の変形による立
位・荷重の困難が 2 例, 骨粗奬症による胸腰椎圧迫骨 折や骨盤骨折が 2 例, 中下位頚椎亜脱臼による脊髄症 が 1 例で, 5 例中 3 例がムチランスタイプであった.

今回の多関節置換例で，人工関節以外に何らかの RA 病変に対する手術が行われていたのは 27 例, 43.5 \%であった（表 5). 歩行障害の原因となる足趾の変 形や足関節の破壊に対し足趾形成術が 12 例，足関節 固定術が 4 例に行われ，また麻痺により歩行障害の原 因となった頚椎病変に対し除圧固定術が 7 例に行われ

表 2 Group 別にみた患者背景

\begin{tabular}{c|c|c}
\hline \hline & Group 1 (50 例) & Group 2 (12例) \\
\hline RA 発症年齢 (平均) & 38.0 才 & 33.8 才 \\
\hline 罹病期間 & 21.1 年 & 23.3 年 \\
\hline 初回手術時年齢 & 54.4 才 & 53.3 才 \\
\hline $\begin{array}{c}\text { 最終手術後 } \\
\text { follow 期間 }\end{array}$ & 3 年 & 3 年 4 カ月 \\
\hline
\end{tabular}

表 3 藤林による移動能力の分類（文献 1 ）より引用）
$3 \mathrm{a}$ 立ち上がり・階段・ 0.5 $1 \mathrm{~km}$ 歩行可
b 杖等を用いて $a$ が可
c 庭程度まで歩行可

$\mathrm{d}$ 屋内歩行可

4a 非実用性歩行

b 実用性のある車椅子動作

c 実用性のない車椅子動作

d 寝たきり

表 1 死亡例

\begin{tabular}{|c|c|c|c|}
\hline & 死 亡 例 & 5 例 & \\
\hline \multicolumn{2}{|c|}{ 死亡時年齢 } & 48 オ〜 71オ & 平均61.2才 \\
\hline \multicolumn{2}{|c|}{ 最終手術から死亡までの期間 } & 2 年 4 年 6 力月 & 平均 3 年 3 力月 \\
\hline \multirow[t]{4}{*}{ 死 因 } & 肺 炎 & 2 例 & \\
\hline & 脳出血 & 1 例 & \\
\hline & 心不全 & 1 例 & \\
\hline & 急性搼炎 & 1 例 & \\
\hline \multirow[t]{2}{*}{ 置換関節 } & 3 関節 & 3 例 & \\
\hline & 4 関節 & 2 例 & \\
\hline
\end{tabular}



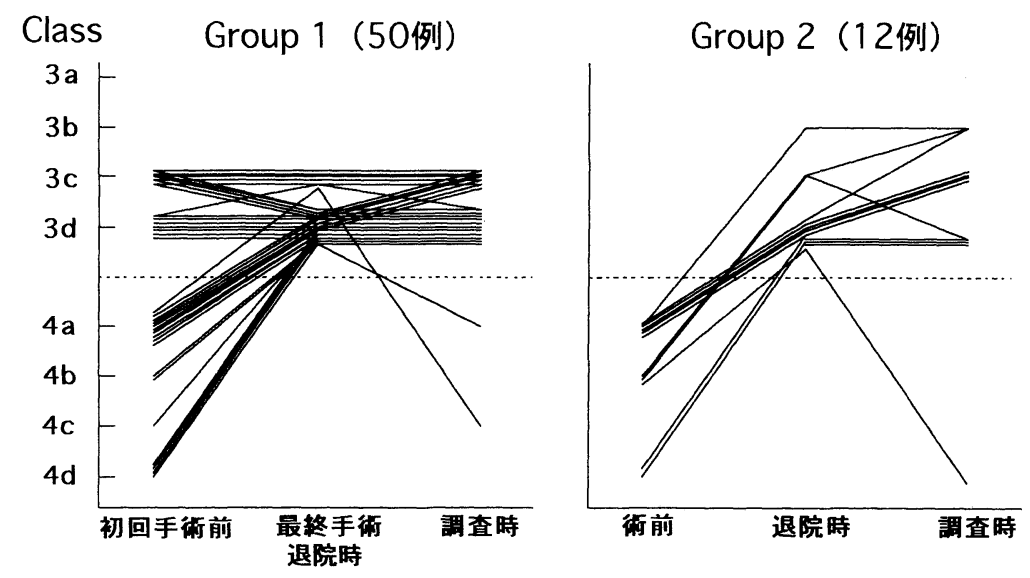

図 1 移動動作の推移

表 4 移動能力悪化例

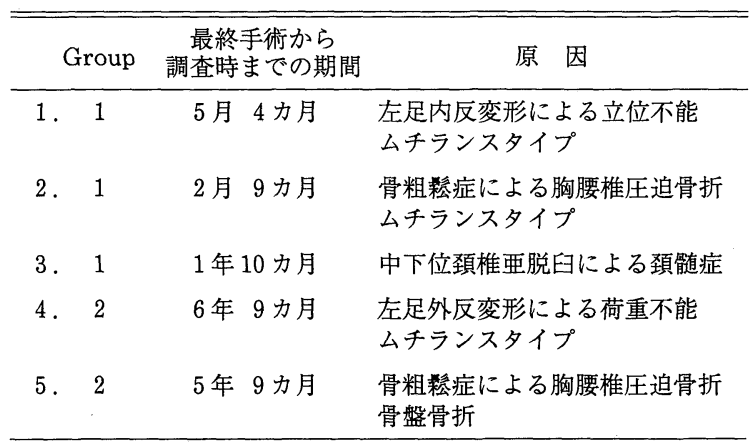

表 5 人工関節以外の手術

\begin{tabular}{lr}
\hline \multicolumn{2}{c}{27 例 $(43.5 \%)$} \\
足趾形成術 & 12 例 \\
足関節固定術 & 4 例 \\
顗椎除圧固定術 & 7 例 \\
膝関節滑膜切除 & 6 例 \\
手関節滑膜切除 & 7 例 \\
\hline
\end{tabular}

ていた. その他では TKR 前に膝の滑膜切除をうけて いたのが 6 例，手関節滑膜切除が 7 例にみられた.

またGroup 2 の症例において, 術前後での RA 活 動性の変化を調べた (図 2). 術後, 赤沈, CRP と もに低下し術後 1 年でともに術前の值に戻っていた. Lansbury 指数は術後長期に改善が得られていた.

調査時にloosening は 2 股， 2 膝にみられたがい ずれも痛みや歩行障害の原因とはなっていなかった。

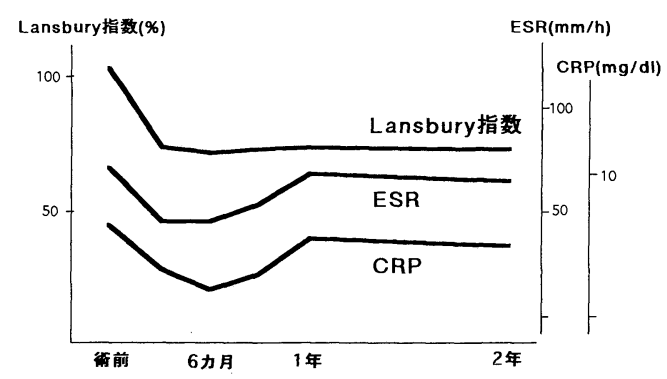

図 2 Group 2 における, 術後の炎症所見, Lansbury 指数の推移

表 6 再置換例

\begin{tabular}{ccc}
\hline \hline & $\begin{array}{c}\text { 手術からRevision } \\
\text { までの期間 }\end{array}$ & 原 因 \\
\hline $1 . \mathrm{THR}$ & 14 年 2 カ月 & loosening \\
$2 . \mathrm{THR}$ & 12 年 & 感染 \\
$3 . \mathrm{THR}$ & 8 年 & loosening \\
$4 . \mathrm{THR}$ & 4 年 7 カ月 & loosening \\
$5 . \mathrm{TKR}$ & 2 年 & 感染 \\
\hline
\end{tabular}

全体のうちで再置換をうけていた症例が 5 例（4 股, 1膝）にみられた（表 6). THR の 3 例が loosening によるもので, THR, TKR の 1 例ずつが感染によ るものであった. いずれの症例も他施設で再置換術を うけていたが, 再置換により歩行能力は維持されてお りレ線経過も順調であった。 


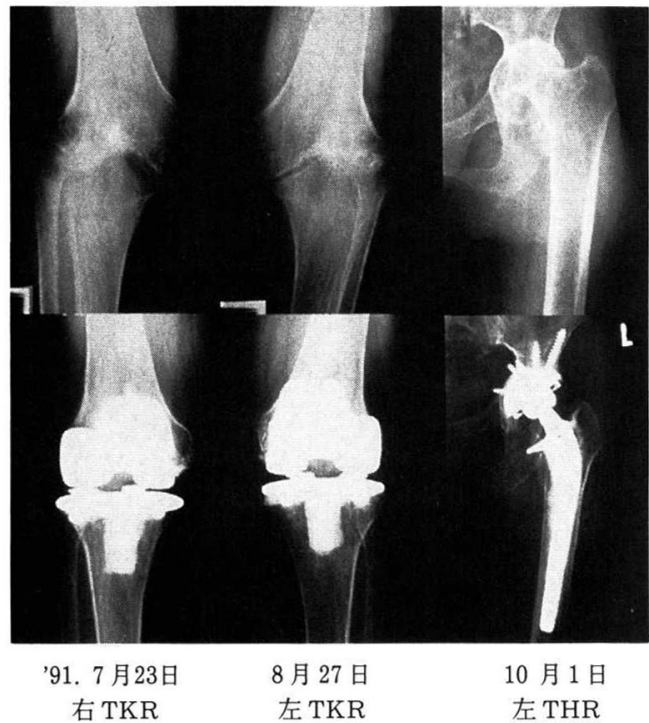

図 3 症例 1 . 約 2 年間寝たきりであった患者に一期 的な 3 関節置換術を行った。

症例

症例 1 (図 3). 71 才女性. RA 罹病歷 43 年. 当科 受診前に約 2 年間寝たきりであった患者で, 両滕とも 90 度の高度の屈曲拘縮があった. 91 年 7 月 3 日にま ず両膝の後方解離術を行い, 7 月 23 日，8 月 27 日に 二次的に左右の TKR を行い，さらに10月 1 日に左 THR を施行し, 術後約 4 カ月間のリハビリの後に退院 となった．現在ステッキで外への散歩も可能で, 藤林 の分類では, 術前 $4 \mathrm{~d}$ が調查時 $3 \mathrm{c}$ と改善している.

症例 2 (図 4). 62 才女性. RA 罹病歴 17 年. 徐々 に下肢の関節破壊が進行し, 83 年左 THR , 85 年右 $\mathrm{THR}, 86$ 年 4 月と 6 月に左右の THR を行い, 以後 歩行能力は良好で, ステッキで $2 \sim 3 \mathrm{~km}$ 歩ける状態 であった．しかし 93 年 1 月ごろより両上下肢の脱力 を自覚し 3 月より歩行障害が出現. C4/5 を中心し た中下位䅡椎での脊髄の圧迫による myelopathy で, 同年 6 月䅡椎後方除圧固定術 $(\mathrm{O} \sim \mathrm{T} 4)$ を行い, 現 在室内のみであるがステッキでの歩行が可能である.

\section{考察}

RAによる関節破壊のうちでも下肢関節, 特に膝, 股関節の破壊は歩行能力を低下させ ADL を大きく障 害する．これに対し多関節置換を含めた TKR, THR

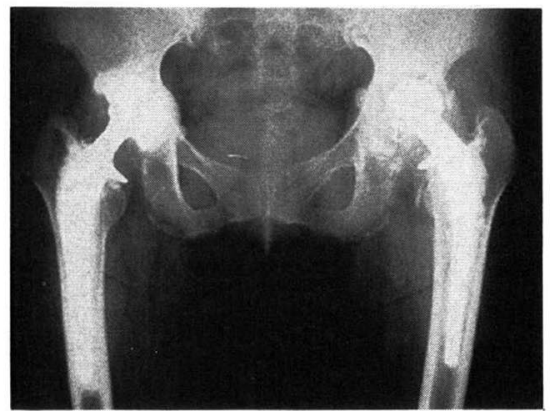

83 年左 '85 年 右 THR

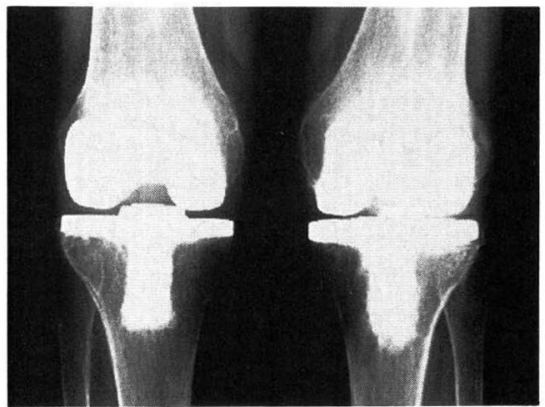

' 86 年 6 月 右 TKR

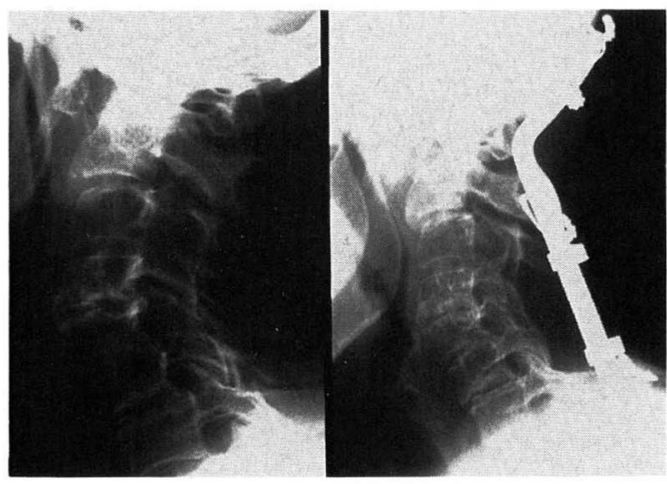

'93 年 6 月

頝椎後方除圧固定術.

図 4 症例 2 . 関節破壊の進行とともに順次人工関節 置換術を行ってきたが, 頚椎病変のために, 歩 行能力が低下し, 後方除圧固定術を行った.

は今回の調査でも明らかなように, 歩行能力の改善に 有効な治療法である。また，結果に示したように一期 的置換により, 寝たきりの症例でも移動能力の獲得は 十分可能であり, 多関節の滑膜切除の効果により約 1 年は消炎効果が期待でき2)6), 関節痛の消失により Lansbury 指数の長期にわたる改善も得られる. 多関 節置換による全身蔵器への影響はほとんどないとされ ており ${ }^{6)}$ ，また最近当科では自己血輸血およびセルセ 
イバーによる術後出血回収により同種血輸血はほほ全 例で回避できる，当科でも，多関節置換をきっかけに 全身状態の悪化した症例はなく, 特に大きな合併症の ない患者であれば，多関節置換による全身への悪影響 はほとんどないといえる，以上より，多関節に破壊が および寝たきりとなった症例でも，本人に意欲があり またリハビリテーションによる筋力回復が見込まれ， 骨質が保たれているものは一期的置換術の適応と考え ている. 一期的な多関節置換術を行う際の優先順位に ついては意見の別れるところであるが3)，われわれは 破壊や変形の強い関節あるいは痛みの強い関節から行 うことにしている.

多関節置換術は，さらに長期の経過観察を要すると はいえ多くの症例で良好な成績が得られていた。しか し多関節置換にいたる症例はほとんどが RA の活動 性が高い症例であり，その後も歩行能力の維持の障害 となる問題点が生じてくる. 今回の調査でも明らかと なった足部・頝椎の RA 病変や骨粗䇗症にもとづく 胸腰椎圧迫骨折などがそれである．またムチランス型 $\mathrm{RA}$ では RA 活動性が高く術後の問題点が多いこと が指摘されている4). 足部や䅡椎の RA 病変による歩 行能力の低下に対しては, 装具療法や追加手術により 改善あるいは維持は可能である。これに対し，骨粗溗 症による胸腰椎の圧迫骨折例では治療に難啮し寝たき りへと進行する例が多く，このような症例に対する予 防から治療までの対策が今後の課題であると考えてい る.

\section{ま と め}

(1) RAにおける下肢多関節人工関節置換例の 62 例 について検討した.

(2)退院時には全例で移動動作の改善が得られており, ほとんどの症例では調査時にも移動能力は維持されて いた。

(3)寝たきりかそれに近い症例に対しても一期的な多 関節置換術により良好な移動動作の改善が得られる。

(4) 62 例中 5 例は死亡しており, 生存の 57 例のうち 5 例では調査時に移動動作が悪化していた．悪化の原 因は足部や頚椎の RA 病変や骨粗症症にともなう胸 腰椎圧迫骨折などであった。

(5) RA の多関節置換例では, 術後長期に歩行能力 を維持するためには，足部や䅡椎病変に対する装具療 法や追加手術・骨粗秷症にともなう胸腰椎圧迫骨折に 対する対策・RA の薬剤コントロールなどを含めた総 合的なアフターケアが重要である.

\section{参 考 文 献}

1）藤林英樹ほか：重度リウマチ患者のリハビリテーショ ンと follow up. 理学療法と作業療法, 11:209-217, 1977.

2) 宮本熬仁: RA 手術後の ADL. 関節外科, $11: 353$ 358, 1992.

3）長屋郁郎, 古沢久俊 : 慢性関節リウマチ患者の下肢手 術について。整・災外, 33:1055-1061, 1990.

4）四宮文男, 他 : ムチランス型 RA における多関節置換 術の経過と予後. 整形外科, $43: 319-327,1992$.

5）鈴木昌則, 他：下肢人工関節置換術が RA 活動性と ADLにおよほす影響. リウマチ, $30: 578,1990$.

6）山名征三，他 : 慢性関節りウマチにおける他関節置換 術の全身臓器ならびに免疫能におよほす影響. 関節外科, 11 : 327-331, 1992. 